Historic, archived document

Do not assume content reflects current scientific knowledge, policies, or practices. 



\section{SPRING, 1923}

\section{APR 91923}

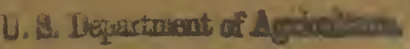

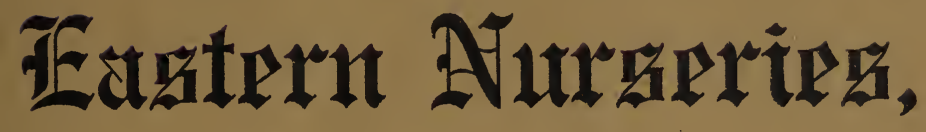

JMrarparated

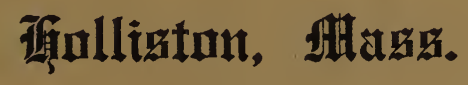

\section{PRICE LIST}

Address all communications to

EASTERN NURSERIES, INC., HOLLISTON, MASS.

Telephone, Natick 345

Telegraph Address, Natick, Mass. 



\section{SPRING, 1923}

\section{Eastern Nurseries, Inc.}

\section{Office and Nurseries, HOLLISTON, MASS.}

SHIPPING SEASON opens about March 20 to April I in the Spring, and continues until May 20 to June I, and opens about October $\mathbf{I}$ in the Fall, and continues until the ground freezes. Shipping for summer planting of Evergreens opens about August isth, Pot-grown plants can be shipped and planted at all times.

ORDERS.-Write plainly and give explicit directions as to address and mode of shipment; otherwise we will forward according to our best judgment. All goods travel at purchaser's risk. We assume no responsibility for the goods after delivery to the forwarding companies.

When losses occur by delays in delivery, claims should be made at once on the forwarding companies.

CLAIMS, to receive consideration, must be made within ten (10) days of receipt of goods.

While we exercise the greatest care to have all Trees, Shrubs and Plants genuine and reliable, and hold ourselves prepared to replace, on proper proof, all that prove untrue, we do not give any warranty, expressed or implied; and in case of an error on our part, it is mutually agreed between the purchaser and ourselves that we shall not at any time be held responsible for a greater amount than the original price of the goods.

PACKING.-We take great care in packing, using damp moss to protect roots. Boxes and bales are charged for at cost.

RATES.-The prices in this list supersede all previous rates, and apply to quantities specified, but two hundred and fifty 250) will be furnished at the thousand rate, twenty-five (25) at the one hundred rate, and five (5) at the ten rate.

This Price List cancels all previous lists and prices are subject to change without notice.

TERMS, CASH WITH ORDERS, except to such persons as satisfy us as to their responsibility. Bills are due when presented and interest will be charged at the rate of six per cent. on bills remaining unpaid December $I$ in Fall and June $\mathbf{I}$ in Spring.

A Certificate of Inspection will accompany each shipment.

Address all communications to office.

EASTERN NURSERIES, INC.,

HOLLISTON, MASS. 



\section{PRICE LIST \\ of}

Eastern Nurseries, Inc.,

William F. Dawson, President

Henry S. Dawson, Vice-President

L. B. DAwson, Sec.-Treas.

Office and Nurseries at HOLLISTON, MASS.

Located twenty-six miles southwest of Boston.

\section{SPRING, 1923}

Our Evergreens are in especially fine condition this year. Most of them have been transplanted recently and all of them are in excellent condition for Spring planting. We wish to call special attention to our small Evergreens suitable for hedges, group planting and window-boxes, and to our large specimens for immediate effects. Many of these specimens are of urusual beauty and can be moved on platforms, at special prices, which we will gladly quote upon request.

Look on pages II to 16 at our list of Pot-grown Scotch Heather and other ground covers.

A cordial invitation is hereby extended to visit our nursery at any time for the purpose of plant study, or for inspection of saleable stock.

EASTERN NURSERIES, INC.

\section{EVERGREEN TREES AND SHRUBS}

The prices of Evergreens include the burlapping of balls.

Abies balsamea Balsam Fir

Each $10 \quad 100$

ro to I2 ft. ..... \$I 2 to $\$ 15.00 \$ \$$

concolor silver fir

All beautiful specimens

5 to $12 \mathrm{ft}$. . . I 2.00 to 60.00

Fraseri She Balsam

I2 to I5 ft. ....... 25.co

homolepis (brachyphylla) Nikko Fir

7 to $15 \mathrm{ft}$. spec. . . I6.50 to 45.00

nordmanniana Nordmann's Fir

$12 \mathrm{ft}$. spec. . . 60.00 to 70.00

pectinata

I2 to $14 \mathrm{ft}$. XXX spec. . 60.00

Veitchil Japanese Silver Fir

I 2 to $15 \mathrm{ft}$. XXX spec. 
Andromeda floribunda See Pieris

\section{Each}

100

Azalea ledifolia (indica alba) White Indian Azalea

6 to 8 in. bushy 4 in. pots . \$1.50 \$12.50 \$

Euonymus radicans acutus Narrow-leaved Euonymus

3 yr. str. f. g. . . . $\quad .85 \quad 7.50$

$\begin{array}{lll}3 \text { yr. str. pot-grown } \quad .85 & 7.5^{\circ}\end{array}$

carrieri Broad-leaved Euonymus

3 yr. strong . . . $\quad .50 \quad 4.00 \quad 35.00$

4 yr. 6 . . . . . $\quad .65 \quad 5.00 \quad 40.00$

large specimens 10 to 12.00

reticulatus (narrow leaf)

$\begin{array}{lllll}3 \text { yr. . . . . } & .40 & 3.50 & 25.00\end{array}$

vegetus Round-leaved Euonymus

$\begin{array}{llll}3 \text { yr. strong . . . } & .50 \quad 4.00 \quad 35.00\end{array}$

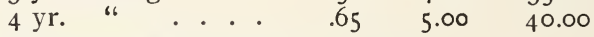

Juniperus chinensis pfitzeriana Pfitzer's Juniper

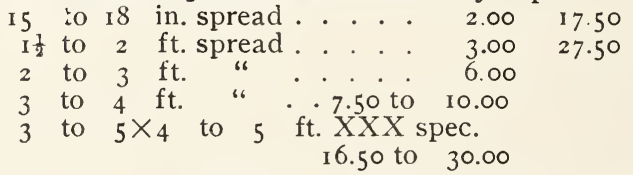

sargentil Sárgent's Trailing Juniper

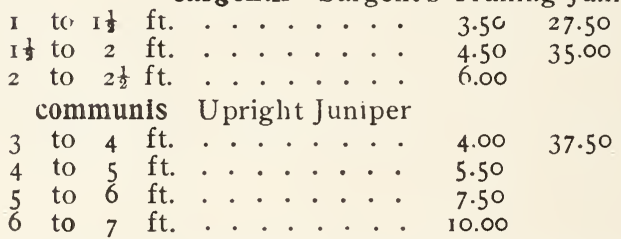

Note. The upright Juniper is one of the very hardiest evergreens, and one of the most satisfactory for the New England climate. It keeps its color all winter, and fruits when still quite small.

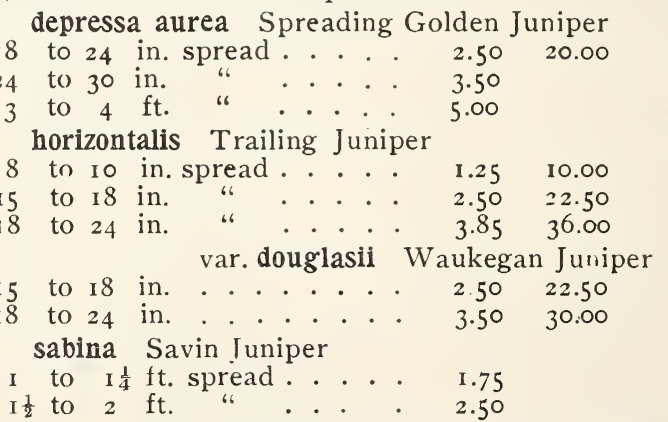

tamariscifolia Tamarisk-leaved Juniper

I to $\mathrm{I} \frac{1}{2} \mathrm{ft}$. spread ..... 3.50

I $\frac{1}{2}$ to 2 ft. " . . . . 5.00

Plant Bearberry and Scotch Heather near the sea 
Juniperus virginiana Red Cedar

\section{Each}

6 to $7 \mathrm{ft}$. . . . . . \$ \$ $9.00 \$ \$$

7 to 8 ft. tr. IOI9 ... II.50

8 to 9 ft. tr. $1919 \ldots$. . 16.50

9 to $10 \mathrm{ft}$. $\operatorname{tr} .1919 \ldots 22.50$

ro to $30 \mathrm{ft}$. XXX spec. 35 to 115.00 virginiana glauca Blue Cedar

5 to $6 \mathrm{ft}$....... 8.50

6 to $7 \mathrm{ft} \ldots \ldots \ldots$ I . . I 3.50

7 to 8 ft. tr. I9i9 ... I6.50

8 to $9 \mathrm{ft}$. tr. I9I9 .. 22.50

9 to $10 \mathrm{ft}$. tr. I9I9 ... 30.00

Note. The Blue and Red Cedars listed above have been growing in our own nurseries and are beautiful specimens recently transplanted and in perfect condition for moving this spring.

virginiana keteleeri

7 to $8 \mathrm{ft}$. spec. . . . 15.00

kosteril Koster's Spreading Juniper

3 to $4 \mathrm{ft}$. $\times 4-5 \mathrm{ft}$. spec.

tr. $1920 \cdots 16.50$ to 30.00 schottel

8 to ro $\mathrm{ft}$. XX spec. 20 to 25.00 tripartita Spreading Cedar

3 to $4 \mathrm{ft}$. spec ... 10.00

4 to 5 ft. spec. .... 12.00

5 to $6 \mathrm{ft}$. spec- .... 15.00

Leucothoe Catesbaei Catesby's Leucothoe

I2 to 18 in. clps. ... 2.2520 .00

Picea albertiana Alberta Spruce

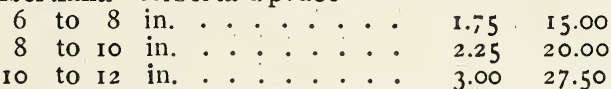

A charming symmetrical evergreen, which grows so slowly that it will stay in scale for many years. We have a large stock of this desirable novelty.

alcocklana Alcock's Spruce

8 to Io $\mathrm{ft}$........ I0.0c

I0 to I2 ft. ...... I 5.00

5-6 68 ft. spec. . . . 55.00

canadensis (alba) White or Cat Spruce

I 4 to $16 \mathrm{ft}$. $X X X$ spec. 35 to 50.00

excelsa clanbrasillana Dwarf Spruce

$2 \frac{1}{\mathrm{z}} \mathrm{ft} . \times 3-3 \frac{1}{2} \mathrm{ft}$. $\operatorname{tr} 1920 \quad 30.00$

nana compacta

3 to 4 ft. $\times 3-3 \frac{1}{2} \mathrm{ft}$. tr. $1920 \quad 30.00$ parvifolla Dwarf Spruce

$2 \times 2$ ft. tr. 192I ... I0.00

3 to $4 \mathrm{ft}$. tr. r 920 ... 25.00

Remonti Remont's Dwarf Spruce

2 to $2 \frac{1}{2} \mathrm{ft} \ldots \ldots$ I 2.50

3 to $4 \mathrm{ft} \ldots \ldots . . .17 .50$

5 to $6 \mathrm{ft}$. XXX spec. 40 to 60.00 
Note. Some of our Dwarf Spruce are wonderful specimens, and most of them have been moved within a year. For formal notes or for the foreground of Evergreen plantings these plants are admirably adapted

Picea orientalis Oriental Spruce

$$
\begin{aligned}
& 5 \text { to } 6 \mathrm{ft} \text {. broad. . \$10 to } \$ 12.50 \${ }^{10} \$ \\
& \text { pungens Green Colorado Spruce } \\
& 6 \text { to } 7 \text { ft. tr. } 1920 \text {... Io.co } \\
& 7 \text { to } 8 \text { ft. spec. tr. } 1920 \text {. } 12.00 \\
& 8 \text { to } 10 \mathrm{ft} \text {.spec.tr. } 192015 \text { to } 30.00 \\
& \text { glauca Colorado Blue Spruce } \\
& 5 \text { to } 6 \mathrm{ft} \text { tr. } 1920 \ldots . . \quad 10.00 \\
& 6 \text { to } 7 \mathrm{ft} \text { tr. } 1920 \ldots . .12 .00 \\
& 7 \text { to } 8 \mathrm{ft} \text { tr. } 1920 \ldots 15.00 \\
& 8 \text { to } 10 \mathrm{ft} \text {. tr. } 1920 \text {. . I5 to } 20.00 \\
& \text { IO to } 12 \mathrm{ft} \text {. tr. } 1920 \text {. } 25 \text { to } 50.00 \\
& \text { kosteri Koster's Blue Spruce } \\
& 5 \text { to } 6 \mathrm{ft} \text { tr.pl. 1920... } 13.75 \\
& 6 \text { to } 7 \text { ft. } \\
& 7 \text { to } 8 \text { ft. " } \quad \text { " . . . } 20.00 \\
& 8 \text { to } 10 \mathrm{ft} \text {. " " } 25.00 \text { to } 40.00
\end{aligned}
$$

All our specimens of Colorado Spruce, both the Blue forms and the Green forms, were transplanted two years ago and are now in an ideal condition for planting in permanent places.

Pleris (Andromeda) floribunda Mountain Fetter Bush $\mathrm{I} \frac{1}{2}$ to $2 \mathrm{ft}$. spread . . . 6.00

Pinus cembra Swiss Stone Pine

$$
\begin{aligned}
& 3 \text { to } 4 \mathrm{ft} \text {. . . . . . } 5.0045 .00 \\
& 4 \text { to } 5 \text { ft. ...... } 7.5070 .00 \\
& 5 \text { to } 6 \mathrm{ft} \text {....... } 9.0080 .00
\end{aligned}
$$

The Swiss Stone Pine is one of the most beautiful of all pines for formal work. The tree is very slow growing, consequently is important for use as accents where one wishes an accent which will stay in scale many years. Our plants are all beautiful specimens.

flexilis Limber Pine

$$
3 \text { to } 4 \mathrm{ft} \text {. . . . . . . . } 4.00 \quad 35.00
$$

montana mughus Mugho or Dwarf Mountain Pine

I5 to 18 in. spread . . . . $\quad 2.25 \quad 20.00$

I $\frac{1}{2}$ to 2 ft. "

2 to $2 \frac{1}{2} \mathrm{ft}$.

$2 \frac{1}{2}$ to $3 \mathrm{ft}$. " . . . . . 5.004500

3 to $3 \frac{1}{2} \mathrm{ft}$. ". . . . $6.00 \quad 55.00$

$3 \frac{1}{2}$ to $4 \mathrm{ft}$. . . . . . 7.5070 .00

4 to $5 \mathrm{ft}$.... I 5 to 20.00

Our entire block of Mugho Pines was transplanted two years ago, and they are now in wonderful condition for planting. Among them are many very fine specimens of the various types of this useful plant. 
PInus strobus White Pine

\section{Each}

100

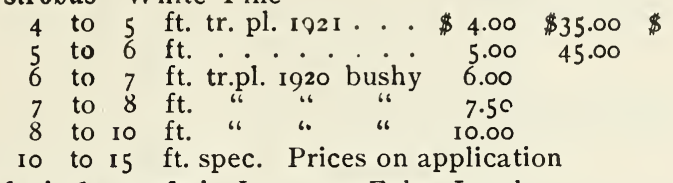

Pseudolarix kaempferi Japanese False Larch 5 to $6 \mathrm{ft}$. spec. . I I.50 to 16.50 Pseudotsuga douglasi Douglas Spruce

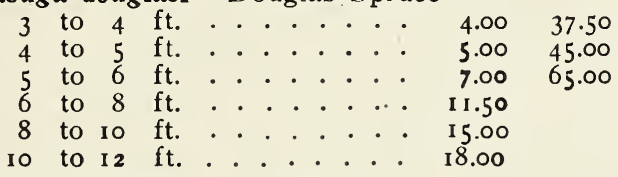

Pyracantha coccinea Fire Thorn

$$
\text { I } 2 \text { to } 15 \text { in. bushy .... I. } 50 \text { I3.50 }
$$

Retinospora obtusa Obtuse-leaved Japanese Cypress

3 to $3 \frac{1}{2} \mathrm{ft}$. . . 6.00

filicoides Fern-leaved Cypress

4 to $5 \mathrm{ft}$....... 6.00

nana Dwarf Hinoki Cypress

2 to $2 \frac{1}{2} \mathrm{ft}$...... 8.50

youngil Golden Obtuse-leaved Cypress

6 to $7 \mathrm{ft}$. . . I I 2.50 to 15.00

pisifera Pea-fruited Japanese Cypress

8 to $10 \mathrm{ft}$. . . I 16.50 to 22.50

12 to $15 \mathrm{ft}$..... 25 to 50.00

aurea Golden Japanese Cypress

4 to $5 \mathrm{ft}$. . . . . . . . $5.50 \quad 50.00$

8 to $9 \mathrm{ft}$....... I5.00

9 to ro ft. ...... 2 I.00

filifera Thread-branched

Japanese Cypress

$2 \frac{1}{2}$ to $3 \mathrm{ft}$....... 4.50

6 to $7 \mathrm{ft}$. . . . 16.50 to 21.00 plumosa Plume-like Japanese Cypress

6 to $8 \mathrm{ft}$. XX spec. . . I6.50

Io to $12 \mathrm{ft}$. spec. . . 20 to 30.00

I 2 to I 4 ft. $\times 5-6 \mathrm{ft}$. 30.00 to 60.00

aurea Golden Plume-like

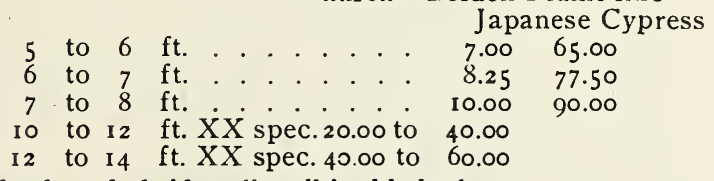

Rhododendron hybrids, all well budded plants

Album Elegans Blush white
$\begin{array}{llll}2 & \mathrm{ft} . & . & .\end{array}$ 


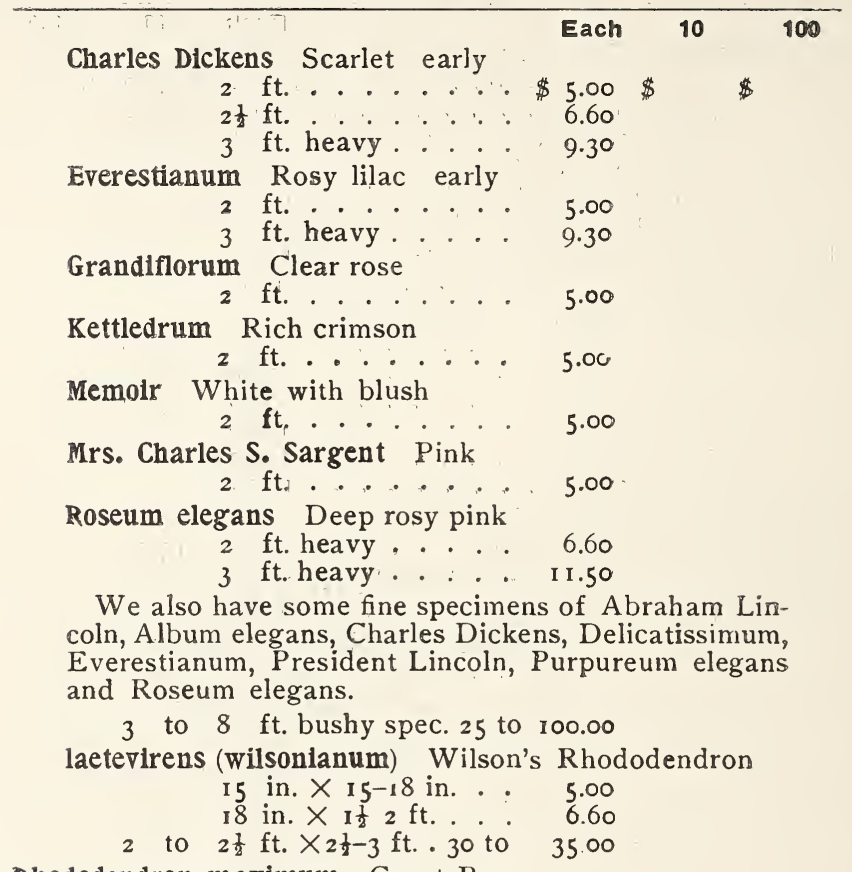

Rhododendron maximum Great Bay

nursery grown

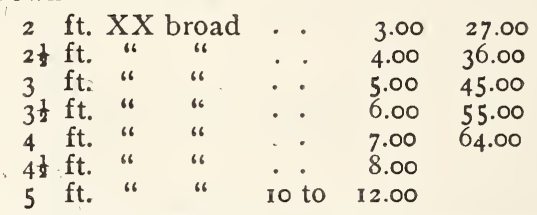

COLLECTED CLUMPS F.O.B, our shipping point in Pennsylvania in carload lots.

$$
\begin{aligned}
& 2 \text { to } 5 \mathrm{ft} \text {. mixed clumps at } \$ 510 \text { per carload } \\
& 5 \text { to } 8 \mathrm{ft} \text {. XXX broad specimen clumps }
\end{aligned}
$$

Prices on application

We make a specialty of collecting Rhododendron Maximum in carload lots. The plants vary in size from it to $5 \mathrm{ft}$. From 65 to 350 plants can be put into a car, depending upon the size of the plants. We ship only first class plants.

Taxus baccata repandens Spreading Yew

15 to 18 in. spread compact 2.50 canadensis Canadian or Ground Yew

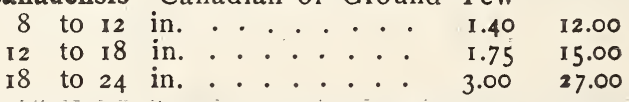


Taxus cuspldata Japanese Yew

\section{Each}

I2 to 18 in. $X$ I 8 in. spread $\$ 3.85 \quad \$ 33.00 \$$

It to $2 \mathrm{ft}$. $\times 2-2 \frac{1}{8} \mathrm{ft}$. spread $8.25 \quad 77.00$

2 to $2 \frac{1}{2} \mathrm{ft}$. $\times 3 \mathrm{ft}$. spread . 15.00

Our Taxus cuspidata are all heavy plants, recently transplanted. We believe there is no finer stock of this indispensable Evergreen in this country.

cuspldata densa Compact Dwarf Japanese Yew

$$
\begin{aligned}
& 8 \text { to } 12 \text { in..... } 3.50 \\
& \approx \text { to } 15 \text { in...... } 4.50 \\
& \text { nana (brevifolla) Dwarf Japanese Yew } \\
& 8 \text { to } 12 \text { in. spread ... } 2.75 \quad 22.50 \\
& \text { I to } 1 \frac{1}{2} \mathrm{ft} \text {. ...... } 3.8533 .00
\end{aligned}
$$

Thuya occidentalis American Arbor Vitæ

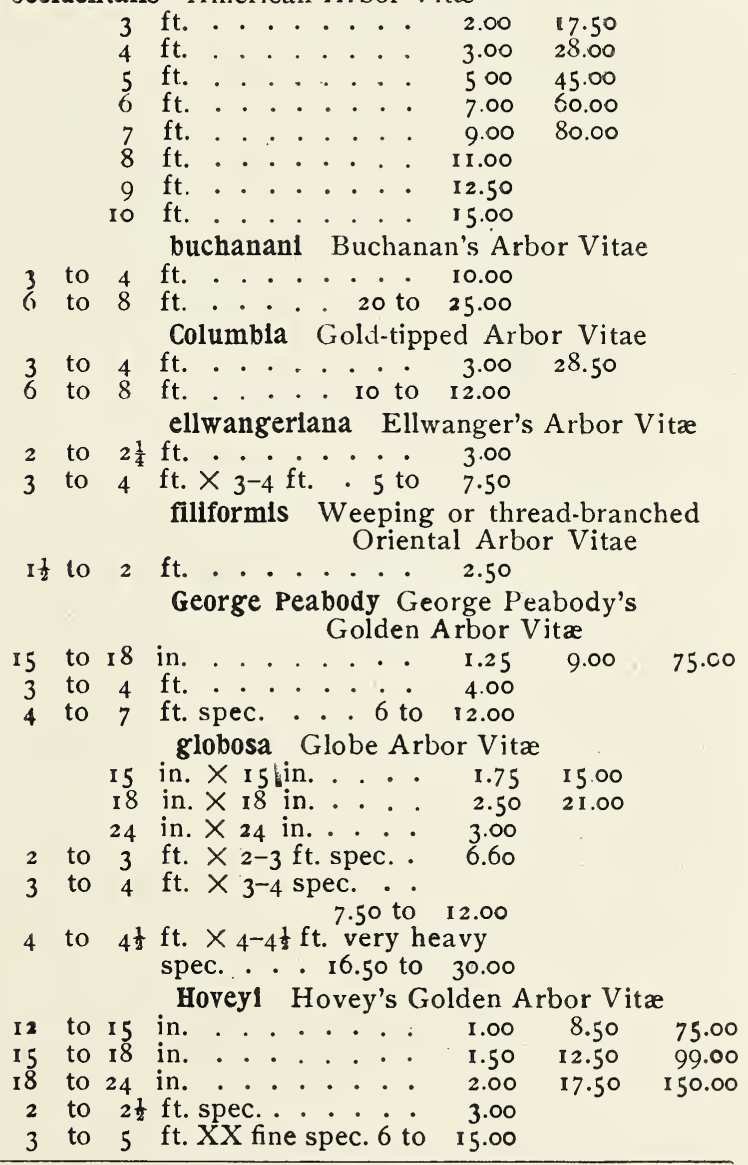

For prices see pages $11-12$ 


\section{Each}

10

100

Thuya occidentalis Little Gem Little Gem Arbor Vitae 8 to 12 in. spread.... \$2.00\$17.50\$ pyramidalis Pyramidal Arbor Vita

\begin{tabular}{|c|c|c|c|c|c|c|}
\hline 2 & to & $2 \frac{1}{2}$ & $\mathrm{ft}$. & . . & 2.00 & 15.00 \\
\hline $2 \frac{1}{2}$ & to & 3 & . . . & . . & 2.50 & 21.00 \\
\hline 3 & to & $3^{\frac{1}{2}}$ & . . . . & . . & 3.25 & 30.00 \\
\hline $3^{\frac{1}{2}}$ & to & 4 & ft. & . & 4.00 & $37 \cdot 50$ \\
\hline 4 & to & $4 \frac{1}{8}$ & ft. & . . & 5.00 & 45.00 \\
\hline $4 \frac{1}{2}$ & to & 5 & $\mathrm{ft}$. & . . & 6.00 & 55.00 \\
\hline & to & 6 & ft. - & - $\cdot$ & $7 \cdot 50$ & \\
\hline & to & 7 & ft. . . & - & 10.00 & \\
\hline & & & Reidil Reid's & Arbor & Vitae & \\
\hline 2 & to & 3 & tt. • • • • & - & $3 \cdot 50$ & 30.00 \\
\hline & to & 4 & ft. heavy . . & - & 7.50 & \\
\hline & to & 5 & $\begin{array}{l}\text { ft. XXX spec. } \\
\text { Rosenthalli }\end{array}$ & . $\cdot$ & I 6.50 & \\
\hline & & & $\cdot \cdot \cdot \cdot \cdot$ & - $\cdot$ & 2.00 & 17.50 \\
\hline & & & & & 2.50 & $22.5^{\circ}$ \\
\hline
\end{tabular}
vervaeneana Vervaen's Arbor Vitae

2 to $3 \mathrm{ft}$........ 3.0025 .00

6 to $10 \mathrm{ft}$. heavy spec. I 2 to 30.00 warreana (siberica) Siberian Arbor Vitæ

15 to 18 in. ....... $2.00 \quad$ I $7.50 \quad 150.00$

18 to 24 in. . . . . . . $2.50 \quad 22.50$

2 to $2 \frac{1}{\mathrm{t}} \mathrm{ft} . \ldots . . .3 .0027 .50$

$2 \frac{1}{2}$ to $3 \mathrm{ft}$...... 4.00

3 to $3 \frac{1}{2} \mathrm{ft} . \cdots . . .240$

$3 \frac{1}{2}$ to $4 \mathrm{ft}$. . . . . . . 5.50

4 to $5 \mathrm{ft}$. spec. . . . . 7.50

5 to $6 \mathrm{ft}$. XX spec. 16.50 to 22.50 Waxen

12 to $\mathrm{I} 8$ in. . . . . $1.75 \quad \mathrm{I} 5.00$

5 to 6 ft. $\times 3-5 \mathrm{ft} \mathrm{spec}$. 40 to 55.00

woodwardli Manning's Globe Arbor Vitae

$\begin{array}{llll}12 & \text { in. } \times 12 \text { in. } \ldots . . & 1.65 & 15.00 \\ 15 & \text { in. } \times 15 \text { in. } . . . & 2.00 & 17.50 \\ 18 & \text { in. } \times 18 \text { in. } . . . & 3.00 & 27.50\end{array}$

2 to $2 \frac{1}{2} \mathrm{ft}$........ 4.25

Most of our Arbor Vitaes have been transplanted within the last two years, and are in prime condition for hedges or specimens.

Tsuga canadensis American Hemlock

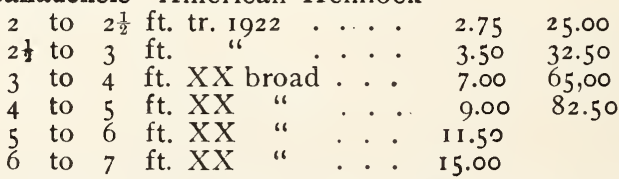

Our Hemlocks, too, have been transplanted recently and all are beautiful, broad, specimens, which came through last winter unharmed.

pendula Sargent's Weeping Hemlock 2 to $3 \mathrm{ft.}$... 7.50 to 10.00 


\section{LIST OF POT-GROWN PLANTS}

Which can be shipped and planted at all times

\begin{tabular}{|c|c|c|c|}
\hline \multicolumn{4}{|l|}{ Abelia rupestris Arbutus Shrub } \\
\hline Abelia rupestris Arbutus Shrub & $\$ .80$ & & $\$$ \\
\hline 4 in. pots & 1.25 & 10.00 & 75.00 \\
\hline tostaphylos uva-ursi Bear-berry & & & \\
\hline $2 \frac{1}{8}$ in. pots $\mathrm{I} y \mathrm{r}$. & 40 & 3.50 & 27.50 \\
\hline $2 \frac{1}{2}$ in. pots 2 yr. & .70 & 6.00 & 45.00 \\
\hline 4 in. pots heavy & 1.25 & 10.00 & 90.00 \\
\hline
\end{tabular}

Azalea ledifolia (indica alba) White Japanese Azalea
4 in. pots
$1.50 \quad 18.50$

Calluna rulgaris Scotch Heather, and named varieties

Scotch Heather, the "Bonnie Purple Heather" of song and verse, is a lovely, low-growing evergreen shrub, 6 in. to $3 \mathrm{ft}$. in height, of the Heath Family, covered in midsummer with small, bell shaped purple flowers, borne on slender spikes. These flowers stay in good condition for some weeks, and if cut while fresh will hold their color and charm all winter. Honey bees, too, are attracted to Scotch Heather and make from it a honey that is considered very choice. This plant is widely known as invaluable for planting in full sun in sandy soil: it is also most attractive as an edging to beds of Rhododendrons, Laurel, etc., and in Rock Gardens. This little plant gives most satisfaction when planted from pots. Besides the common purple Heather there are many varieties which give variation in the height of plant, color of flowers. and season of bloom. Below we offer a list of varieties, all of which are pot grown, sturdy plants. $2 \frac{1}{2}$ in. pots

var. alba White Scotch Heather, early blooming, with light green foliage, white flowers, grows 12 to 15 inches. $2 \frac{1}{2}$ and 3 in. pots

var. alba elata Tall White Heather. Late blooming, very tall, straight growth. Foliage soft dark green, flowers white, grows 18 to 24 in. $2 \frac{1}{8}$ and 3 in. pots

var. alba hammondil Hammond's White Heather. Midseason, tall upright growth, foliage rich deep green, flowers white, grows 8 to 24 in. high. $2 \frac{1}{2}$ and 3 in. pots

var. alba minor Small-leaved White Heather. Mid-season, tall bushy growth, 15-20 in. high, foliage very fine light green; flowers white. 3 in. pots

var. alba pllosa Late blooming, tall growth $18-20$ in. high, foliage of soft grayish green, flowers white. 3 in. pots.

var. alba rigida Late, low rigid growth, foliage rich deep green, flowers white. $2 \frac{1}{2}$ and 3 in. pots

var. alportil Late blooming, tall straight growth to 24 in. foliage deep rich green, turning purple in autumn. Flowers rosy carmine. $2 \frac{1}{2}$ in. pots

var. aurea Golden foliage and pink flowers, one of the best of those with colored foliage. 3 in. pots

var. compacta Late blooming. Low compact, moss-like growth, 4 to 6 in. high, of bright, rich green. Flowers pale lavender. 3 in. pots 
var. cuprea Mid-season. Straight medium growth 12 to 15 in. high, foliage bright, almost yellowish green, turning to rich glowing red in autumn. Flowers purple. $2 \frac{1}{2}$ and 3 in. pots

var. hirsuta (tomentosa) Midseason. Low compact growth 4 to $;$ in. high, foliage soft gray, flowers purple. $2 \frac{1}{2}$ and 3 in. pots

var. humilis Low growing, with rich green foliage. Flowers, midseason, white. 3 in. pots

var. hypnoides Late blooming. Low-spreading growth, 6 to 12 in. high. Foliage soft deep green, flowers deep pink. $2 \frac{1}{2}$ and 3 in. pots

var. monstrosa Loose growth. Flowers pink. 3 in. pots

var. rosea Mid-season. Tall, straight-growing, with deliicate pink flowers. 3 in. pots.

var. rubra Early blooming, with low spreading growth, 6 to 12 in. high. Foliage soft green turning purple in autumn. Flowers rosy carmine. $2 \frac{1}{2}$ and 3 in. pots

var. tenella Early blooming. Low growth with slender spikes of dainty lavender flowers. $2 \frac{1}{2}$ in. pots.

Prices on Heather and varieties:

$$
\begin{aligned}
& 2 \frac{1}{2} \text { in. pots . . . . . . . } \begin{array}{cccc}
\text { Each } & \$ 10 & 100 \\
3.50 & \$ 4.50 & \$ 35.00
\end{array} \\
& 3 \text { in. pots....... } \quad .80 \quad 7.00 \quad 55.00
\end{aligned}
$$

Campanula carpatica Carpathian Harebell

$2 \frac{1}{2}$ in. pots....... . . . 30 $2.50 \quad 18.00$

var. alba White Carpathian Harebell

$2 \frac{1}{2}$ in. pots....... . . 30 $2.50 \quad 18.00$

Note: The Cotoneasters are among the most important groups of hardy plants which have recently been brought before the public. All of them have attractive foliage and conspicuous berries. Of those listed below C. adpressa, horizontalis and its variety perpusilla, and C. microphylla are of low-spreading growth, have small glossy, evergreen-like foliage and bright red berries which stay on the shrubs well into the winter. The plants of this group of Cotoneaster are particularly adaptable for use in rockery, on the edge of low shrubberies or on slopes. C. Dielsiana, divaricata and salicifolia floccosa are of more shrub-like growth, with long graceful branches, glossy leaves and bright red berries. All of these plants are hardy and do well in any good well-drained garden soil, but require plenty of water during the first year after transplanting, and take hold much more satisfactorily when transplanted from pots than from the field.

Cotoneaster adpressa
2 yr. 3
in. pots
$3 \mathrm{yr}$.
in.
2 yr. 3 in. pots..... $1.40 \quad 11.50$

Plant Bearberry and Scotch Heather near the sea 


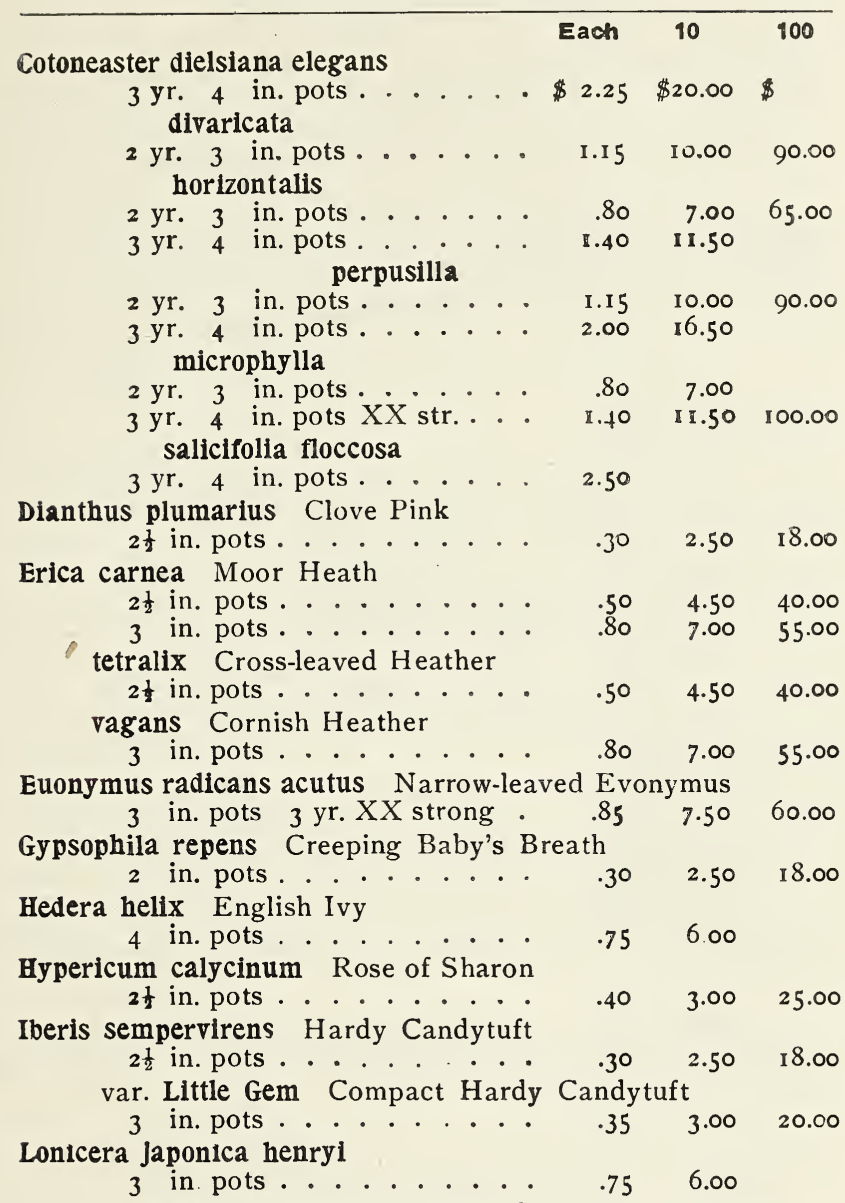

nitida Evergreen Honeysuckle

A tall-growing, graceful shrub, with long slender branches thickly clothed with small shining evergreen leaves which turn rich purple in the autumn. This beautiful shrub is not quite hardy in the vicinity of Boston; but for southern New England, Long Island, New York and south and west it should prove a valuable garden hedge plant.
$2 \frac{1}{2}$ in. pots . . . . . . .55
4 in. pots . . . . . 1.00
6 in. pots XX specimens .. $\quad$ I.50
pileata

This Honeysuckle, also, is evergreen. The growth of this 
shrub is somewhat stiff, and spreading, the foliage $\frac{1}{2}$ to I inch long, rather box-like, and bright shining green. While still a small plant L. pileata is covered with small yellow flowers which produce in early autumn beautiful transparent berries of clear light purple. Like L. nitida this shrub does not always survive the severe winters of this climate; but in southern New England and south and west it is one of the most useful and beautiful of the new shrubs. It will serve as a specimen shrub in the garden, a shrub for rockgardens, or as a low, wide-spreading hedge.

$$
\begin{array}{lllll}
4 & \text { in. pots . . . . . . . . . } & \$ 1.00 & \$ 7.50 \\
6 & \text { in. pots . . . . . . . . . } & 1.25 & 10.00
\end{array}
$$

Pachistima canbyi

24 in. pots 2 yr. . . . . . . . $\quad .55 \quad 5.00 \quad 45.00$

3 in. pots 3 yr. ..... $\quad .70 \quad 5.50 \quad 50.00$

Pachysandra terminalis Japanese Spurge

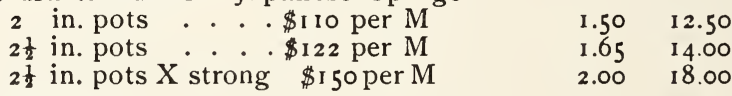

Phlox subulata alba White Ground Phlox

2 in pots............. $30 \quad 2.50 \quad 18.00$

G. F. Wilson Lavender Ground Phlox

2 in. pots........ $\quad 3.25 \quad 25.00$

Potentilla tridentata

2 in. pots XX strong .... $\quad \begin{array}{llll}35 & 3.25 & 25.00\end{array}$

Rosa Alberic Barbier A wichuraiana hybrid climber; glossy foliage and large deep cream flowers late in June

3 in. pots....... .756 .00

American Pillar Climber of strong growth with rich glossy foliage and huge clusters of large, cherry-colored flowers

$$
3 \text { in. pots........ . . . . } 75 \quad 6.00
$$

Apple Blossom A Dawson hybrid, of rambler habit like the Dawson Rose, but with clear shell-pink flowers Early
4 in. pots . . . . . . 1.75

Crimson Rambler
4 in. pots.
.75
6.00

Dawson A Dawson hybrid climber of rambler habit. Flowers semi-double deep pink in large clusters. Early
3 in pots .
.60
5.00
4 in. pots XX strong .... $\quad .75 \quad 6.00$

Daybreak A Dawson hybrid. Climber with glossy foliage and large clusters of single deep salmon pink flowers in July

$$
4 \text { in. pots....... . . } 1.00 \quad 7.50
$$

Dorothy Perkins Climber with glossy foliage and clusters of late-blooming, deep-pink, double flowers
4 in. pots
.75
6.00

Dr. Van Fleet Strong growing climber with glossy foliage and large double shell pink flowers in early July
3 in. pots......... 85
4 in. pots . . . . . . 1.15

Plant Bearberry and Scotch Heather near the sea 


\section{Each}

Rosa excelsa Climbing wichuraiana hybrid bearing clusters of double brilliant red flowers late in season
3 in.
n. pots
$\$ .75 \$ 6.00$

Harrison Old-fashioned yellow Rose

3 in. pots........ I. I. . 10.00

Helenae Shrub with slender branches and large clusters of pure white fragrant flowers. Considered by the Arnold Arboretum one of the handsomest of all roses brought from China by Mr. Wilson
4 i
in. pots.
2.25

hibernica gravesii Irish Rose. Single flowered pink rose closely related to the Scotch Rose
4 in. pots . . . . . . 1.50

Hugonis Father Hugo's Rose. An upright rose with stems covered in early spring witn single clear yellow flowers before the foliage appears
4 in. pots.......
$2.00 \quad 17.50$

Jackil Low-growing or trailing rose from Korea with long-pointed glossy foliage, and large clusters of white flowers with yellow centers. Blooms late.
4 in. pots .
2.00

Lady Duncan A Dawson hybrid, semi-climber, with rich green rugosa-like foliage, and large clear salmon-pink flowers, blooming in late June. Absolutely free from injurious pests
4 in. pots........
6 in. pots . . . . . . .
$1.75 \quad 15.00$
2.50

Lady Gay Pink climber much like Dorothy Perkins
4 in.
n. pots
.75
6.00

Minnie Dawson Dawson hybrid. Rambler of the Dawson habit, the flowers small double white borne in large clusters

$$
4 \text { in. pots....... } 1.75
$$

moyesil Tall shrub of loose growth, with large pointed foliage and small deep red flowers, followed by long orange-red fruits. Introduced from China by $\mathrm{E}$. $\mathrm{H}$. Wilson

$$
4 \text { in. pots...... } 2.00
$$

multiflora catheyensis The pink multiflora from China

$$
3 \text { in. pots....... } 1.00 \quad 7.50
$$

Pauline Dawson A Dawson hybrid climber or pillar rose of good foliage and large single deep pink flowers

$$
3 \text { in. pots....... T.25 }
$$

rugosa repens alba Climbing or creeping white-flowered rugosa hybrid, with glossy foliage and large star-shaped white flowers

$$
3 \text { in. pots ......... } 1.25 \quad 10.00
$$

seashell Dawson hybrid. Climber which has glossy foliage and large clusters of large semi double pink flowers, blooming in July

3 in. pots......... 4 in. pots. 1.25 


\section{Each 10}

Rosa Silver Moon Climber with glossy rich foliage and large single cream white flowers, blooming in July
4 in. pots ....... \$1.00\$7.50\$
6 in. pots ....... 1.40
spinosissima Scotch Briar
4 in. pots......
$1.25 \quad 10.00$

Tausendschon Climber. Good foliage, flowers large, shell pink fading to white. Late bloomer. July
4 in. pots
.75
6.00

William C. Egan A Dawson hybrid, climber, with good foliage and large very double pink flowers. Late June 3

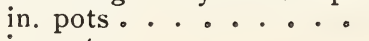
.75
6.50
4 in. pots...... $1.00 \quad 7.50$

We have also a large collection of field grown Roses

Sedum acre Stonecrop

$2 \frac{1}{2}$ in. pots............. $30 \quad 2.50 \quad 18.00$

gray foliage

$2 \frac{1}{2}$ in. pots ............ $30 \quad 2.50 \quad 20.00$

Silene maritima

$2 \frac{1}{2}$ in. pots............. $30 \quad 2.50 \quad 18.00$

Thymus serpyllum coccineum Red-flowered Thyme

$2 \frac{1}{2}$ in. pots ........ . . 30 $2.50 \quad 18.00$

lanuginosa Woolly-leaved Thyme

$2 \frac{1}{2}$ in. pots............. $30 \quad 2.50 \quad 18.00$

Vaccineum vitis-idaea Mountain Cranberry

Veronica rupestris

$3 \frac{1}{2}$ in. pots heavy ..... $85 \quad 6.00 \quad 50.00$

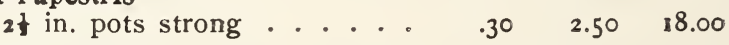

Vinca alba 2 years

$2 \frac{1}{2}$ in. pots.......... $40 \quad 3.5030 .00$

minor 2 years

Viola atropurpurea

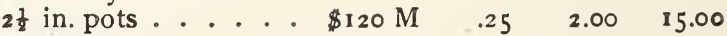

$2 \frac{1}{2}$ in. pots............. $30 \quad 2.50 \quad 20.00$

Plant Bearberry and Scotch Heather near the sea 


\section{TREES, SHRUBS AND VINES}

Acanthopanax (aralia) pentaphylla Five-leaved Aralia

$$
4 \mathrm{ft} . . . . . . . \$ 30 \$ 4.50 \$
$$

Acer dasycarpum (saccharinum) Silver-leaved Maple

8 to ro $\mathrm{ft}$. . . . . . . 1.25 I I.50

I 8 to $20 \mathrm{ft}$. 3 to 5 in. cal.

$$
6 \text { to } 15.00
$$

ginnale Tartarian Maple

8 to ro ft. XX bushy . . $4.50 \quad 40.00$

negundo Ash-leaved $\mathrm{M}$ aple

6 to $8 \mathrm{ft}$.......... I.25 10.00

platanoides Norway Maple

10 to $12 \mathrm{ft}$. $\mathrm{I} \frac{1}{2}$ to 2 in. cal. . $2.50 \quad 22.50$

14 to 18 ft. 4 to 6 in. cal. .

17.50 to 30.00

var. Schwedleri Schwedler's Maple

I2 to $14 \mathrm{ft} .2$ to 4 in. cal. . . 6 to 7.50

rubrum Red or Swamp Maple I6 to $20 \mathrm{ft}$. 3 to $4 \mathrm{in.} \mathrm{cal.} \mathrm{.} \mathrm{.} \quad 10.00$

saccharum Sugar Map!e

Io to $12 \mathrm{ft}$...... 2.50

I2 to I4 ft. . . . . 3.00

Actinidia arguta Silver Vine

$$
5 \text { yr. XX strong... } 1.50 \quad \mathbf{1 2 . 5 0}
$$

This is one of the very best vines, for quick growth, for clean luxurious foliage, and for growing in shade. Akebia quinata Akebia

$$
3 \text { yr. ....... } \quad .75 \quad 7.00
$$

Andromeda speciosa See Zenobia puverulenta

Aristolachia sipho (macrophylla) Dutchman's Pipe

large specimens . . 3.50

Azalea arborescens Fragrant White Azalea

I to I $\frac{1}{2} \mathrm{ft}$. bushy .... 2.25

2 to $2 \frac{1}{\mathrm{ft}}$. bushy .... 3.00

$2 \frac{1}{2}$ to $3 \mathrm{ft}$ bushy

kaempferi Kaemper's Azalea

12 in. XX bushy •. $2.00 \quad 17.50$

15 to 18 in. . . . . $2.75 \quad 25.00$

lutea (calendulaceae) Flame Azalea

$2 \frac{1}{2}$ to $3 \mathrm{ft}$. . . 4.50

pontica Ghent Hybrids

$$
\text { It to } 2 \mathrm{ft} \text {....... } 2.75 \quad 25.00
$$

2 to $2 \frac{1}{\mathrm{ft}} \mathrm{ft} \cdot{ }_{4} .00 \quad 36.00$

We can furnish the following Ghent Hybrids:

Bouquet de Flore Rose with white stripe

18 to 24 in.

Coccinea speciosa Clear orange red

18 to 24 in.

Gloria Mundi Clear orange

18 to 24 in. 
Azalea Guelder Rose Pink, yellow lip

Each 10

15 to 18 in.

Pallas Bright red

18 to 24 in.

Sang de Gantbruges Rich carmine red

I 8 to 24 in.

Unique Orange

18 to 24 in.

mollis var. Hollandia Yellow, flushed with pink

15 to 18 in. ..... $\$ 4.00$

I $\frac{1}{2}$ to $2 \mathrm{ft} . \ldots \ldots . . .500$

2 to $2 \frac{1}{2} \mathrm{ft}$....... 6.00

vaseyi Southern Pink Azalea

15 to 18 in. . . . . $2.00 \quad 17.50$

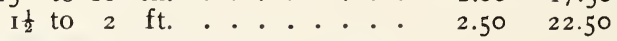

viscosa White Swamp Azalea

2 to $2 \frac{1}{2} \mathrm{ft}$.

3 to $6 \mathrm{ft}$. XX heavy coll. clps.

Berberis thunbergii Japanese Barberry

$$
4 \text { to } 6.00
$$

2 to $2 \frac{1}{\mathrm{l}} \mathrm{ft}$. . . . . . $\quad .554 .00$

$2 \frac{1}{2}$ to $3 \mathrm{ft}$........ $\quad .75 \quad 6.50$

vulgaris Green or Common Barberry

2 to $3 \mathrm{ft}$. For Newland distribution $40 \quad 3.50 \quad 25.00$

Betula papyrifera Paper or Canoe Birch

10 to $12 \mathrm{ft} . \ldots . . . .32 .50 \quad 32.50$

I2 to I4 ft. ...... 5.0040 .00

I 4 to $16 \mathrm{ft}$. . . . . . $6.00 \quad 50.00$

Calycanthus floridus Pineapple Shrub

$$
2 \text { to } 2 \frac{1}{2} \mathrm{ft} \text {. heavy.... . . . } 50 \quad 5.00
$$

Caragana arborescens Siberian Pea Tree

$$
3 \text { to } 4 \mathrm{ft} \text {........ } 1.00 \quad 7.50
$$

Carpinus caroliniana American Hornbeam

ro to $12 \mathrm{ft}$. spec. ... 7.50

Castanea pumila Chinquapin

5 to $6 \mathrm{ft}$. bushy .... $6.00 \quad 50.00$

Cercidiphyllum japonicum

6 to 8 ft. bushy .... 2.75

Chionanthus virginica White Fringe

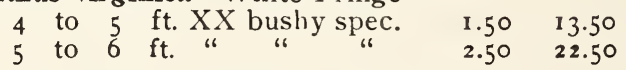

Clematis paniculata Japanese Virgin's Bower

$3 \mathrm{yr}$. strong •... . . $65 \quad 5.50$

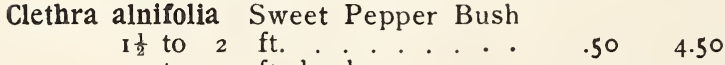

2 to 3 ft. bushy . . . . . $55 \quad 5.55$

Cornus alba (Siberica) Red-twigged Cornel

5 to $6 \mathrm{ft}$....... $50 \quad 4.50$

6 to 8 ft. .......... $50 \quad 5.50$

Cornus amomum (sericea) Silky Cornel
4 to $5 \mathrm{ft}$. . . . . . . $\quad .50 \quad 4.00$

5 to $6 \mathrm{ft}$. . . . . . . . $\quad .55 \quad 4.50$

Plant Bearberry and Scotch Heather near the sea 


Each 10

Cornus controversa Chinese

8 to $10 \mathrm{ft}$. spec. . . . \$11.50 $\$$

florida Flowering Dogwood

3 to 4 ft. bushy .... . 1.2510 .00

4 to 5 ft. bushy .... $1.75 \quad 1500$

mas Cornelian Cherry

2 to $2 \frac{1}{2} \mathrm{ft}$. bushy .... . $\quad .55 \quad 5.00$

paniculata Panicled or Gray Dogwood

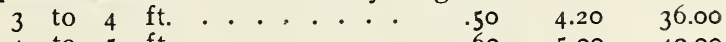

4 to $5 \mathrm{ft}$. . . . . . . . 60 5.0040 .00

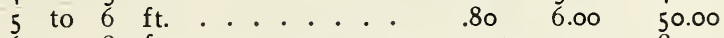

6 to 8 ft. . . . . . . . $1.25 \quad 10.00 \quad 85.00$

stolonifera Spreading Red Ozier

Cotoneaster franchetti

5 to $6 \mathrm{ft}$.......... 85 . 6.50

I to $\mathrm{I} \frac{1}{2} \mathrm{ft}$. bushy .... 1.00

racemiflora var. soongarica

3 to $3 \frac{1}{2} \mathrm{ft}$. bushy, tr. 1922.2 .50

By many people this is considered the most beautiful of all shrubby Cotoneasters. It is of tall growth, has silvery leaves, flowers in clusters and numerous large brilliant red fruits.

\section{wheeleri}

I to $\mathrm{I} \frac{1}{2} \mathrm{ft}$. bushy .... $1.00 \quad 7.50$

For Cotoneaster divaricata, horizontalis and var. perpusilla see Pot-grown Plants, page 13.

Crataegus arnoldiana Arnold's Hawthorn

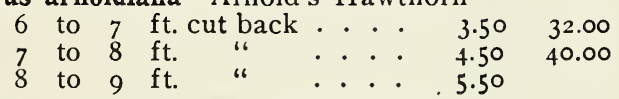

This is one of the rarest and most beautiful of all Hawthorns. It has large white flowers in early spring. Even the young trees offered by us bear quantities of large round edible scarlet fruits in August and September, and, later, the substantial leaves turn a beautiful scarlet. A beautiful small flowering tree, suitable as a specimen, for planting in groups on the edges of woods, or near the sea.

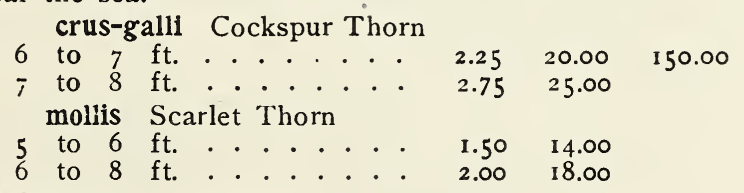

Cydonia japonica Japanese Quince I $\frac{1}{2}$ to $2 \mathrm{ft}$........ $\quad .50 \quad 4.50$

Deutzia gracills Slender Deutzia 8 to 12 in. ...... . . . $40 \quad 3.50$

Lemoinei Lemoine's Deutzia

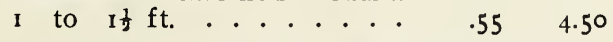


Deutzia scabra Rough-leaved Deutzia

$$
\text { Each } 10 \quad 100
$$

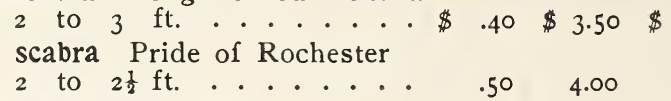

Enklanthus campanulatus

$$
\text { I2 to } 18 \text { in. bushy, . . . } 1.75 \quad 13.75
$$

\begin{tabular}{|c|c|c|c|c|c|}
\hline $3^{\frac{1}{3}}$ & ft. - $\cdot$ & . & - $\cdot$ & .90 & \\
\hline tc & ft. & & - & 1.25 & Io. \\
\hline & ft. spec. & & & $4 \cdot 50$ & \\
\hline $\begin{array}{l}\text { to } 8 \\
\text { to } 10\end{array}$ & $\begin{array}{l}\mathrm{ft} . \\
\mathrm{ft} .\end{array}$ & $\begin{array}{l}B \& B \\
B \& B\end{array}$ & $\therefore 50$ to & $\begin{array}{r}5.00 \\
1000\end{array}$ & \\
\hline
\end{tabular}

Evonymus alatus Cork-barked Japanese Burning Bush

Exochorda grandiflora Pearl Bush

$$
3 \text { to } 4 \mathrm{ft} \text {.......... } 756.00
$$

Forsythia intermedia Golden Bell

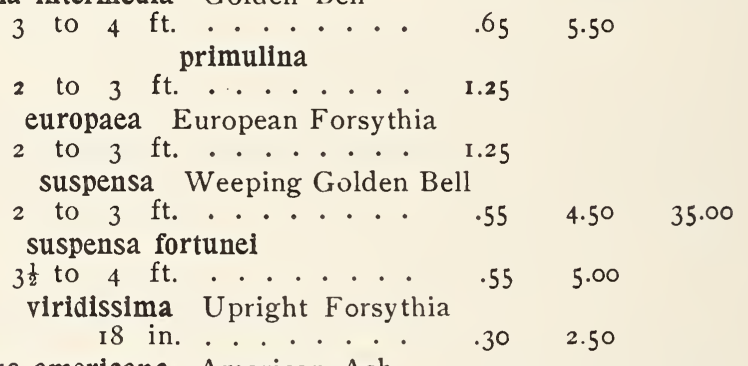

Fraxinus americana American Ash

I2 to $14 \mathrm{ft} .2 \frac{1}{2}$ in. cal. . . . 3.50

Hamamelis virginiana Witch Hazel

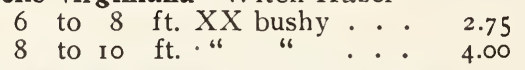

Hydrangea arborescens grandiflora alba

Hills-of-Snow Hydrangeas

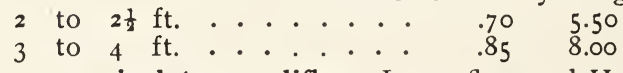

paniculata grandiflora Large-flowered Hydrangea 18 in. ...... $.50 \quad 2.50$

Ilex verticillata Black Alder

$$
3 \text { to } 4 \mathrm{ft} \text {....... . . . . } 50 \quad 5.00
$$

Kerria japonica Globe-flower

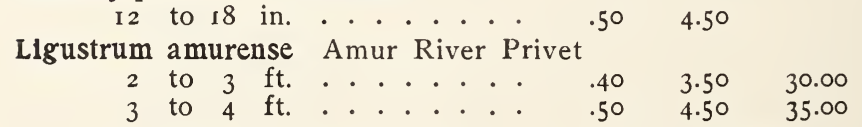

A hardy Privet with the habit of California Privet lbota Japanese Privet

I $\frac{1}{2}$ to 2 ft. bushy ..... . . . $45 \quad 3.50 \quad 30.00$

3 to $4 \mathrm{ft}$............. $85 \quad .85 \quad 7.00 \quad 55.00$

4 to $6 \mathrm{ft}$. . . . . . $1.25 \quad 8.25 \quad 55$ vulgaris Common Privet or Prim

2 to $3 \mathrm{ft} . \ldots . . . . \quad .40 \quad 3.50$

Plant Bearberry and Scotch Heather near the sea 
Lonicera japonica halleana Hall's Honeysuckle

\section{Each}

3 yrs. XX heavy... \$75 \$6.00\$

Maackli Chinese Bush Honeysuckle

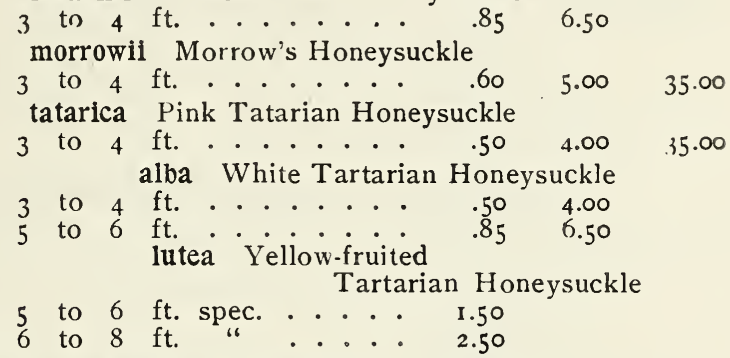

Magnolia soulangeana Soulange's Pink Magnolia

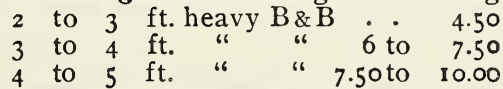

stellata or Halleana Hall's Japanese Magnolia

I $\frac{1}{2}$ to $2 \mathrm{ft}$. XX broad

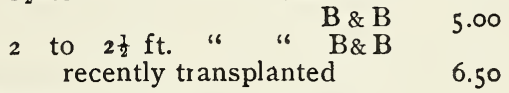

Malus baccata Siberian Crab-apple

6 to $8 \mathrm{ft}$...... 3.50

floribunda Flowering Crab

3 to $4 \mathrm{ft}$........ 1.75

4 to $5 \mathrm{ft} . \mathrm{ft}_{2.25}$

7 to 8 ft. XX heavy spec.

tr. pl. 1921 I6.50 to 27.50

atrosanguinea Red-flowered Crab-apple

5 to $6 \mathrm{ft}$. XX heavy spec. $8.5^{\circ}$

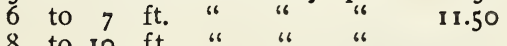

8 to ro $\mathrm{ft}$. " " 6 " 6.50 to 27.50

halliana parkmanni

Parkman's Double Flowering Crab-apple

I t to $2 \mathrm{ft}$. cut back

$$
\begin{array}{lll}
\text { tr. pl. } 1921 & 1.25 & 10.00
\end{array}
$$

ioensis fl. pl. Bechtel's Double Flowering Crab

2 to $3 \mathrm{ft}$...... 1.25

3 to $4 \mathrm{ft.}$....... 1.75

4 to 5 ft. ....... 2.50

niedzwetzkyana Red-dyed Crab

4 to $6 \mathrm{ft}$. XX heavy spec. 5.50

6 to 8 ft. " " "

8 to ro ft. " " " 6.50

Io to $\mathrm{I} 2 \mathrm{ft}$. . . . I6 to 20.00

sargentil Sargent's Flowering Crab-apple

I $\frac{1}{2}$ to $2 \mathrm{ft}$.......... $2.00 \quad 15.00$

spectabilis var. rosea fl. pl.

Double Pink Chines Flowering Crab-apple

3 to $4 \mathrm{ft}$. . . . . . 4.00

For prices see pages $11-12$ 
Myrica cerifera Bayberry

Each $\quad \overline{10} \quad 100$

I8 in. bushy

$\$ .55 \$ 5.00 \$$

Philadelphus avalanche Avalanche Mock Orange

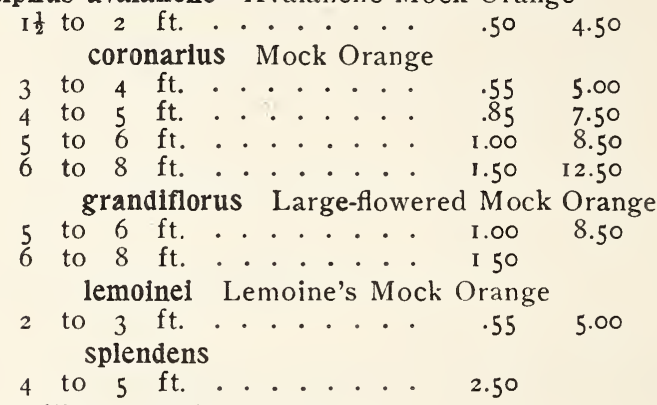

Photinia villosa Deciduous Photinia

4 to $5 \mathrm{ft}$....... 2.5020 .00

Potentilla fruticosa Veitchil Veitch's White Potentilla

I2 to I8 in. bushy .... I.00 7.50

parvifolia Purdonis Deep Yellow Potentilla

15 to 18 in. . . . . 1.007 .50

I 8 to 24 in................ I.25 1000

The white and deep yellow Potentillas are charming shrubs of low habit. Their arching branches are covered with delicate divided leaves, and small single flowers, like tiny roses, continuing to bloom from early spring until frost. As a low shrub in the foreground of shrubbery or for the rockery these shrubs are invaluable.

Prunus serrulata James H. Veitch's Double Rose

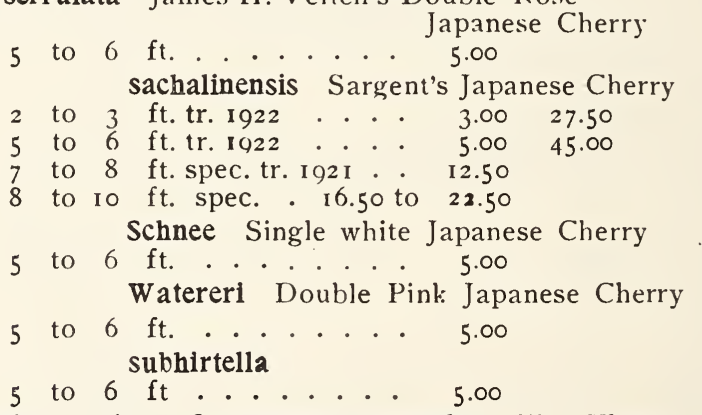

Pyracantha coccinea (Crataegus pyracantha) Fire Thorn

12 to 15 in. bushy .... $1.50 \quad 13.50$

Rhamnus catharticus Buckthom

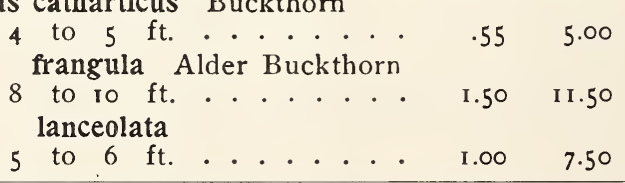

Plant Bearberry and Scotch Heather near the sea 
TREES, SHRUBS AND VINES.

Rhodora canadensis Rhodora

$\begin{array}{cc}\text { Each } & 10 \\ \$ 1.50 & \$ 12.50 \quad \$\end{array}$

Rhodotypos kerrioldes White Kerria

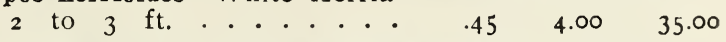

Rhus cotinus Smoke Tree or Purple Fringe

3 to $4 \mathrm{ft}$......... $85 \quad 7.00^{\circ}$

Rosa Alberic Barbier A wichuraiana hybrid climber; glossy foliage and large deep cream flowers late in June
2 to
$3 \mathrm{ft}$.
t. $\dot{X} \dot{X}$ str.
.75
6.00
I. $50 \quad \mathbf{I} 2.50$

American Pillar Climber of strong growth with rich glossy foliage and huge clusters of large, cherry-colored flowers
2 to
I $\mathrm{yr}$.
t. $\dot{\mathrm{X}} \dot{\mathrm{X}}$ str.
.75
$6 . n \circ$
$1.00 \quad 7.50$

Blanc Wouble de Coubert Hybrid Rugosa with strong growth, rich foliage, and pure double white flowers
I to $I \frac{1}{2} \mathrm{ft}$.
9.00

Clothilde Soupert An old-fashioned polyantha rose with good foliage and double white flowers, turning to delicate pink. Blooms all summer.

$$
\text { I yr. . . . . . . . } 75 \quad 6.00
$$

Crimson Rambler Old fashioned climbing rose with rich crimson semi double flowers in late June and early July.

$$
\text { I yr. . . . . . } \quad .756 .00
$$

Dawson A Dawson hybrid climber of rambler habit. Flowers semi-double, deep pink in large clusters. Early r yr. ............ $75 \quad 6.00 \quad 50.00$

Daybreak A Dawson hybrid. A climber with glossy foliage and large clusters of single deep salmon pink flowers in July

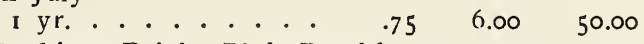

Dorothy Perkins Bright Pink Rambler

$$
\text { I yr. strong..... } \quad .75 \quad 6.00 \quad 50.00
$$

Dr. Van Fleet Strong growing climber with glossy foliage and large double shell pink flowers in early July
I to
ft. 2 yr. . . . . $\quad .75$
2 to $3 \mathrm{ft}$........ 1.50

excelsa Climbing wichuraiana hybrid bearing clusters of double brilliant red flowers late in season
I yr.strong
$.75 \quad 6.00$
2 to $3 \mathrm{ft}$. XX strong. . $1.00 \quad 9.00$

Gruss au Tepletz Red Hybrid Tea

2 yr. strong . . . . . $1.00 \quad 9.00$

Harrison Old-fashioned yellow Rose

2 yr. strong........ 1.25

Hiawatha Climber, single scarlet flowers, white center

$$
\text { I yr. . . . . . . } \quad .75 \quad 6.00 \quad 50.00
$$

Hugonis Father Hugo's Rose. An upright rose with stems covered in early spring with single clear yellow flowers before the foliage appears

$$
3 \text { yr. str. plants } \quad 3.00 \quad 25.00
$$

For prices see pages $11-12$ 


$\begin{array}{rrrr}\text { Each } & 10 & 100\end{array}$

Rosa Lady Duncan A Dawson hybrid, semi.climber, with rich green, rugosa-like foliage, and large clear, salmon-pink flowers, blooming in late June. Absolutely free from injurious pests

\section{3 yr. str. plants $\$ 2.50 \$ 20.00$}

Lady Gay Pink climber much like Dorothy Perkins

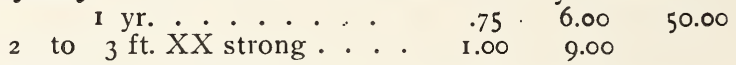

Mme. Plantier Old-fashioned, double-flowered white rose
2 to $3 \mathrm{ft}$
1.00
8.50

Minnie Dawson Dawson hybrid. Rambler of the Dawson habit, the flowers small double white borne in large clusters, early in the season. The Dawson and Minnie Dawson are the earli st to bloom of all climbers, flowering in our vicinity sometimes in late May, always in early June
2 to 1
I yr.
1.00
9.00
$\begin{array}{llll}2 & \text { to } 3 \text { ft. XX strong... } & \text { I.50 } & 12.50\end{array}$

Paul's Scarlet Climber New climbing rose with large double clear scarlet flowers

$$
2 \text { yr....... } 1.25
$$

Pauline Dawson A Dawson hybrid climber or pillar rose of good foliage and large single deep pink flowers

2 to 3 ft. XX strong... I.50

penzance hybrids Bush roses, hybrids of the popular Sweet Briar, having fragrant pink flowers

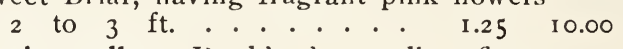

Persian yellow Double deep yellow flowers
I to $\mathrm{I} \frac{1}{2} \mathrm{ft}$. strong.
I. 25
10.00

Purity A large-flowered white climber, similar to Silver Moon, but hardier and flowers more freely

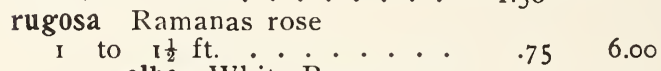

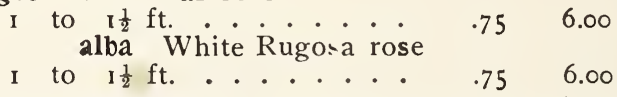

rugosa repens alba Climbing or creeping white-flowered rugosa hybrid, with glossy foliage and large star-shaped white flowers
2 to 3
ft. spread .
I. 50
I 3.50

Seashell Dawson hybrid Climber which has glossy foliage and large clusters of large, semi-double pink flowers, blooming in July

$\begin{array}{llll}1 \frac{1}{2} \text { to } 2 & \mathrm{ft} \text {. spread..... } & \mathbf{1} .25 & \mathbf{1} 1.50\end{array}$

Setigera Prairie Rose climbing

3 to 4 ft. . . . . . . . . $455 \quad 4.50 \quad 40.00$

William C. Egan A Dawson hybrid, climber, with good foliage and large very double pink flowers. Late June. The Egan Rose is one of the very satisfactory climbing Roses. Its foliage is pleasing, and is never attacked by insects, it does not die back in hard winters, and even when very small it is covered with the large, very double fragrant roses

$$
2 \text { to } 3 \mathrm{ft} \text {. . . . . . . } 1.50 \quad \mathbf{2} 2.50
$$


All the Roses listed above are thrifty two to three-year old plants which were planted from pots last spring, and will lift with good roots

Hybrid Perpetual and Hybrid Tea Roses We have a limited supply of Hybrid Roses including Caroline Testout, Dean Hole, Frau Karl Druski, Gen. Jacqueminot, La France and Mme. Edward Herriott ....... . \$1.00 \$9.00 \$

Spiraea callosa alba White Bush Meadow Sweet

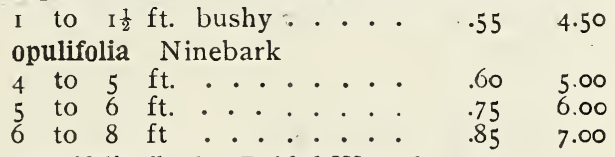

prunifolia fl. pl. Bridal Wreath

2 to $3 \mathrm{ft}$........... $55 \quad 4.50$

Thunbergii Thunberg's Spiræa

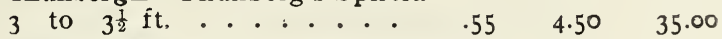

Van Houtteil Van Houtte's Spiræa

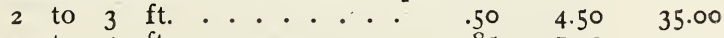

4 to $5 \mathrm{ft}$............ $85 \quad 7.00$

Stephanandra flexuosa

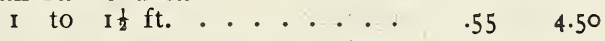

Symphoricarpus racemosus Snowberry

2 to $3 \mathrm{ft}$. . . . . . . . . $\quad .55 \quad 4.50 \quad 35.00$

Syringa japonica Japan Tree Lilac

8 to ro ft. ...... 3.5030 .00

rothamagensis (Climensis) Chinese Lilac

2 to $3 \mathrm{ft}$....... $60 \quad 5.00$

vulgaris Common Purple Lilac

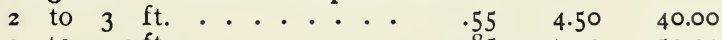

3 to 4 ft. . . . . . . $\quad .85 \quad 7.00 \quad 50.00$

var. alba Common White Lilac

2 to $3 \mathrm{ft}$.......... $45 \quad 4.50 \quad 40.00$

var. Charles $\mathrm{X}$ single dark reddish purple

3 to $4 \mathrm{ft}$....... 2.25

var. Ludwig Spath Deep reddish purple

2 to $3 \mathrm{ft}$........ 1.50

var. Marie Legraye Single white

2 to $3 \mathrm{ft}$. ...... 1.50 I 2.50

var. Michael Buchner Single deep pink

2 to $3 \mathrm{ft}$. heavy .... 1.65 I5.00

var. Mme. Lemoine Double white, very fine

2 to 2 ft. ........ I.50 13.50

var. William Robinson Double Pink

2 to $3 \mathrm{ft}$. heavy.... 1.65 I5.00

Tilla europaea European Linden

Io to $14 \mathrm{ft}$. 4 to 5 in. cal.

6 to 12.00 


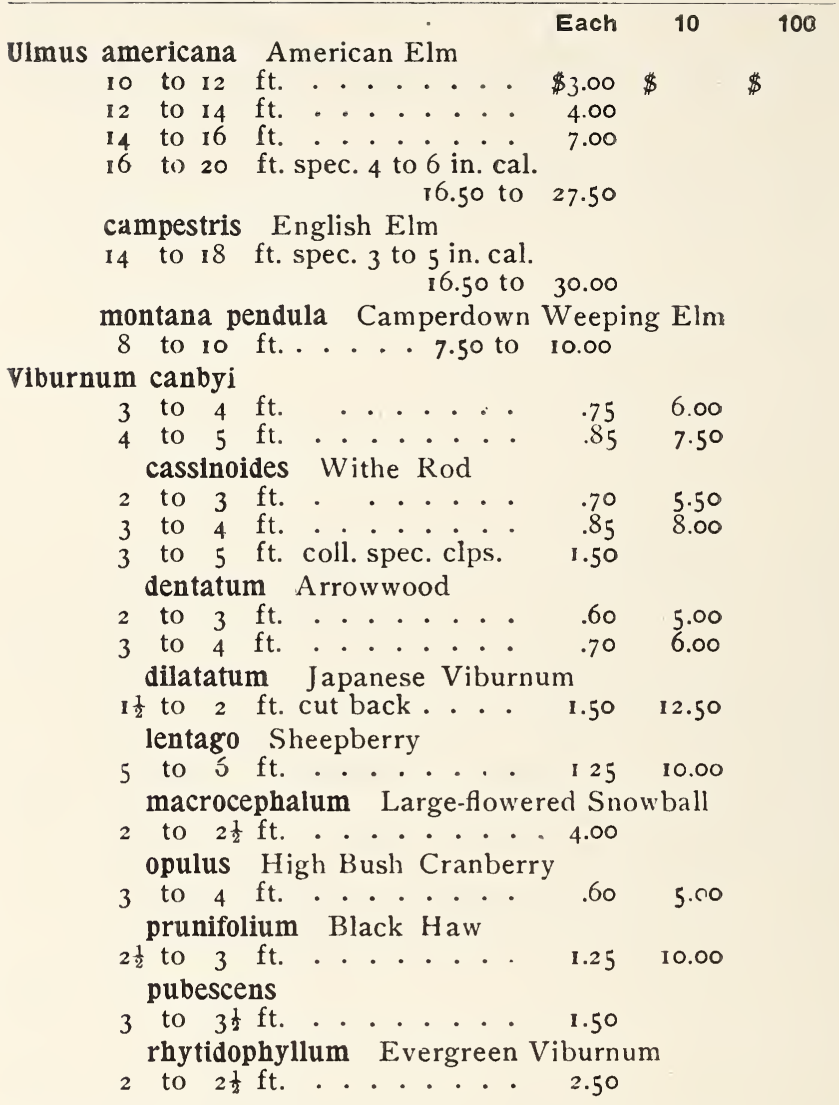

Vitus cordifolia Chicken Grape

$$
3 \text { yrs. ...... } 1.25 \quad 10.00
$$

Wistaria chinensis Blue

$$
5 \text { yrs. ....... } 1.75
$$

multijuga White

Zenobia puverulenta (Andromeda speciosa)

$\mathrm{I} \frac{1}{2}$ to $2 \mathrm{ft}$...... 2.50 


\section{HARDY HERBACEOUS PERENNIALS}

Except where noted 25 cents each, $\$ 2.25$ per ten $\$ 16.00$ per hundred

Achillea ptarmica "The Pearl"

Each $10 \quad 100$

Aconitum acutum Early Aconite . . \$ $.40 \$ 350 \$ 30.00$

Ajuga genevensis Creeping Bugle

Althaea rosea Hollyhock single mixed

Anthemis tinctoria Rock Chamomile

Anthericum liliago St. Bernard's lily

Aquilegia canadensis Wild Columbine

coerulea Rocky Mountain Columbine

nivea grandiflora Early white Columbine

Rose Queen Pink, long-spurred hybrids

Arabis alpina Rock Cress

Arenaria caespitosa Moss-like Arenaria

Armeria maritima Sea Thrift

Aster alpina Alpine Aster

Climax Tall blue Aster .... . $30 \quad 2.50$

ericoldes White Heath Aster

Feltham's Blue Early, medium height, almost clear blue

Lady Trevellyn White

Novae Angliae rubra Tall growing, intense rose pink

shortil Violet blue, medium

tataricus Blue flowers, latest and tallest of Asters

Thompsonil Flowers very large, blue. Low-growing

Baptisia australis False Indigo

Boltonia asteroides False Chamomile

latisquama Pink Boltonia

Campanula carpatica

alba

medium single, white, mauve, pink

Cassia marylandica Wild Senna

Centaurea montana Perennial Cornflower

Cerastium biebersteimil

Chrysanthemum coccineum Pink Daisy

Maximum Shasta Daisy

Uliginosum Giant Daisy

Coreopsis grandiflora Large-flowered Coreopsis

Daphne cneorum Garland Flower

$$
2 \text { yr. clumps … } 1.00 \quad 8.50
$$

Delphineum chinense Chinese Larkspur, blue

hybridum Bella Donna

Blue Butterfly

mixed

Dianthus barbatus Sweet William red, white and pink beauty

caesius Cheddar Pink

plumarius Clove pink 
Digitalis ambigua Yellow Foxglove

Each 10

100

gioxinae flora rosea Pink Foxglove

purpurea Purple Foxglove

alba White Foxglove

Erysinum pumilum

Eryngium amethystinum Sea Holly

Festuca glauca Blue Fescoe Grass

Gaillardia grandiflora Blanket Flower

Geum heldreichii Orange Geum

triflorum Common Avens

Gillenia stipulata

Gypsophila paniculata Baby's Breath

repens Creeping Baby's Breath

Helenium autumnale hoopseii Hoope's Sneezewort

Helianthus maximillianus

Miss Mellish

mollis var. cordatus

muitiflorus

orgyalis

rigidus

Hemerocallis apricot Day Lily

dumortieril Dwarf Orange Day Lily

flava Lemon Lily

fulva Tawny Day Lily

thunbergii Japanese Lemon Lily

Hesperis matronalis Sweet Rocket

Hosta (Funkia) lancifolia Lavender Day Lily

Hypericum adpressum Creeping St. John's Wort

calycinum Rose of Sharon $\$ .45 \quad \$ 400 \quad \$ 30.00$

Iberis sempervirens Hardy Candytuft

Little Gem Dwarf Candytuft

Iris florentina alba White Florentine Iris

Germanica German Iris

Charlotte Patty golden yellow

Fairy Queen white, falls veined in blue

Garrick standards light blue falls a dark blue

Mme. Chereau white, edges of petals blue

laevigata (kaempferi) Japanese Iris

Pallida dalmatica ....... . . . 35 $3500 \quad 25.00$

speciosa

nseudacorus Yellow Flag

siberica Siberian Iris

alba White Siberian Iris

orientalis Oriental Iris

Snow Queen White Oriental Iris

Lepachys pinnata Yellow Cone Flower

Plant Bearberry and Scotch Heather near the sea 
Liatris scarriosa Blazing Star

\section{Each}

10

Linum perenne Perennial Flax

Lupinus polyphyllus White

Pink

Lychnis viscaria splendens

Lysimachia nummularia Money-wort

vulgaris Yellow Loosestrife

Lythrum salicaria Purple Loosestrife

Nepeta Mussini

Oenothera fruticosa youngii Dwarf Evening Primrose

Paeonias mixed large clumps . . . $\quad .55$

Papaver orientale var. Mrs. Perry

Salmon Pink Oriental Poppy

Parthenium hysterophorus Prairie Dock

Phlox amoena Dwarf Phlox

paniculata Albion white with pink eye

Antoine Mercie pale lilac, white star in center

B. Comte Rich, dark crimson red, late blooming

$.35 \quad 3.00$

Boquet Fleuri pure white, crimson eye, very fine

Bridesmaid White with large rosy center

Czarina fine white, tall and late

Eugene Danzanvilliers lilac rose

Ferdinand Cortez pale crimson, very tall, late

Feu de Monde salmon red, tall, late

Gefion Light, clear pink, crimson eye medium $.35 \quad 3.00$

Gen. Van Heutz salmon-red with pure white center, large

Hermione dioarf white, large flowers

H. 0. Wijers white, with large red eye. Low

Independence white, medium, early

James Galloway clear red

Lumineaux bright pink with white star, large flowers

Mme. Meuret bright red

Mme. Pape Carpentier white, large flowers, low

Mme. Paul Dutrie Delicate mauve pink

large flowers, mid-season

Michael Buchner clear pink, large crimson center very tall, late

Mrs. Cook tall, soft magenta pink, very late

Ornament clear rose, very large panicles

Prof. Schlieman pure mauve, crimson eye, late bloomer

Richard Wallace white, deep crimson eye

R. P. Struthers rosy red, with crimson eye 


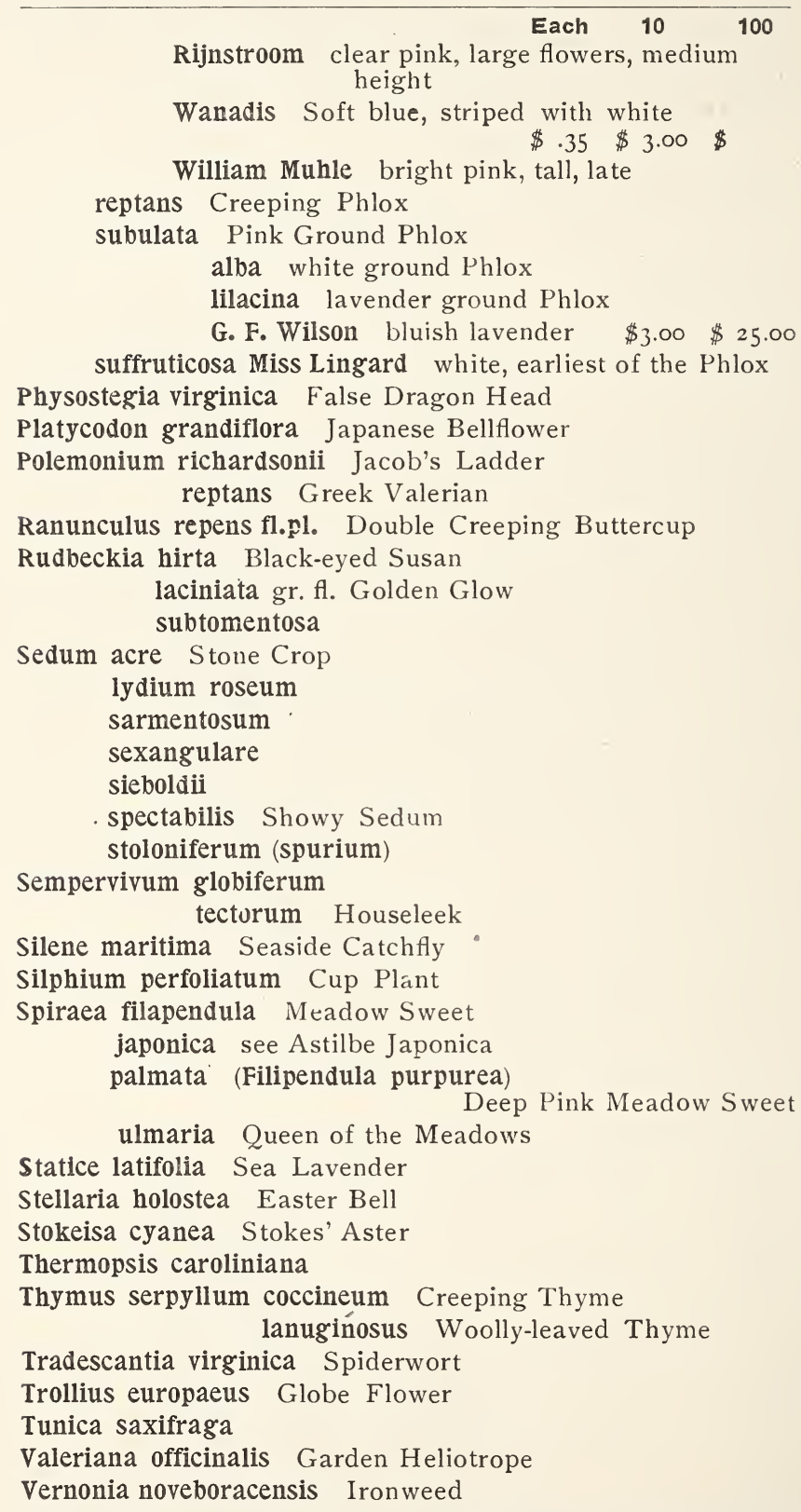


HARDY HERBACEOUS PLANTS.

31

Veronica alpestris See V. serpilifolia

Each

100

gentianoides Gentian-leaved Speedwell

rupestris

spicata Speedwell

var. Maxima Tall Speedwell

serpilifolia Thyme-leaved Speedwell

Viola cornuta Horned Violet

alba White

atropurpurea deep purple

rosea grandiflora

$\$ .35 \$ 3.00 \$$

For prices see pages $11-12$ 



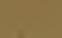

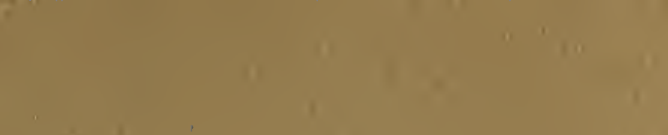

1

1

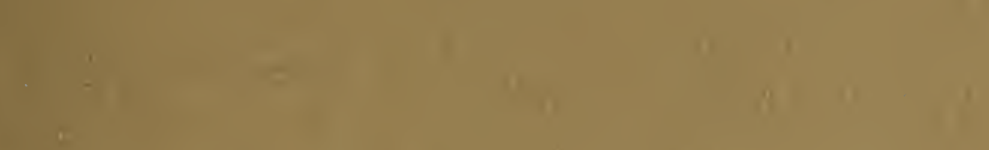

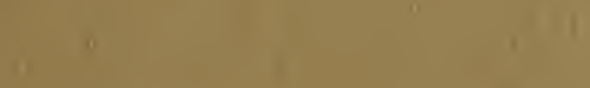

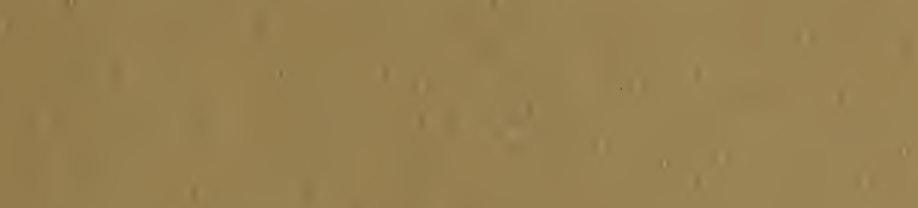

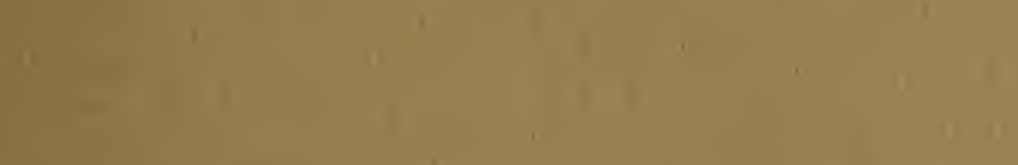$$
\text { 4. }
$$

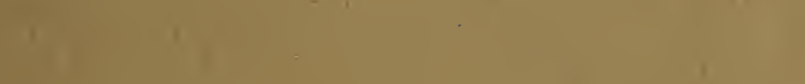

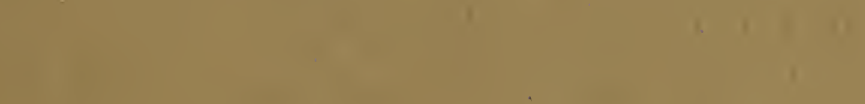

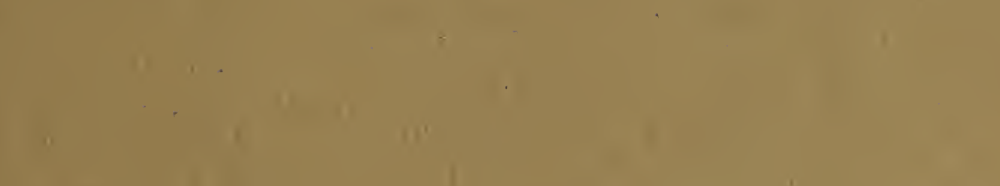

$$
\begin{aligned}
& \text { - }
\end{aligned}
$$

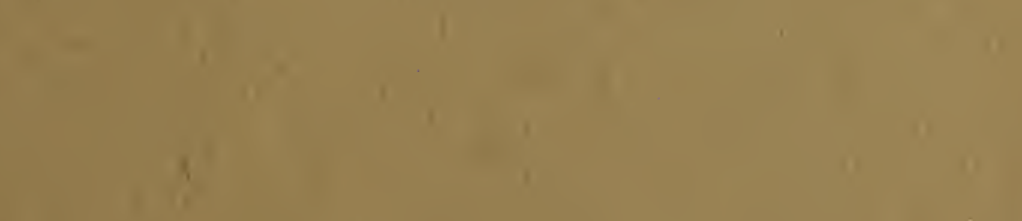

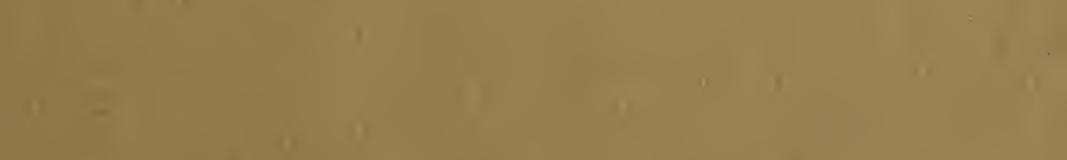
at $\mid$ 


\section{HOW TO REACH OUR NURSERIES}

By train: Take train from South Station, Boston, or from Worcester and other points west, to Framingham. From Framingham, take train or electric car to Holliston. Upon being notified we will be glad to meet at Holliston any persons desiring to visit the Nurseries. Telephone Natick 345 .

By motor: From Boston the best route is via Newton, Wellesley, South Natick; from South Natick take Elliot Street, to Main Street, Sherborn, thence Main Street, Goulding Street, Mill Street, Fiske Street to the Nurseries.

From Worcester take main route to Framingham, from Framingham follow the street car track to Holliston Centre, turn sharp to left up Central Street, thence Fiske Street to the Nurseries. 